\title{
Attraction of Urastoma cyprinae (Turbellaria: Urastomidae) to the eastern oyster Crassostrea virginica
}

\author{
Nicole T. Brun ${ }^{1, *}$, Andrew D. Boghen ${ }^{1}$, Jacques Allard ${ }^{2}$ \\ ${ }^{1}$ Department of Biology, Université de Moncton, Moncton, New Brunswick E1A 3E9, Canada \\ ${ }^{2}$ Department of Mathematics and Statistics, Université de Moncton, New Brunswick E1A 3E9, Canada
}

\begin{abstract}
Urastoma cyprinae Graff, 1882 has been reported on the gills of various bivalve species, including the eastern oyster Crassostrea virginica. While earlier workers refer to $U$. cyprinae as a commensal, recent findings reveal that the 'gill-worm' can be pathogenic to its molluscan host and may, therefore, also be considered to be parasitic. To determine whether there exists a definite attraction of $U$. cyprinae to oysters, a series of experiments were conducted using specially designed glass chambers. Results indicate that $U$. cyprinae is negatively phototactic and that it is more attracted to oysters when compared to other molluscan species such as mussels and clams. U. cyprinae was found to be highly attracted to isolated oyster mucus, and, to a lesser extent, to mucus-coated gill tissue. Findings confirm that the presence of $U$. cyprinae in oysters is not coincidental and that mucus plays an important role in attracting the worms to its host.
\end{abstract}

KEY WORDS: Turbellaria $\cdot$ Urastoma cyprinae $\cdot$ Molluscs $\cdot$ Crassostrea virginica $\cdot$ Gills $\cdot$ Oyster mucus

\section{INTRODUCTION}

Urastoma cyprinae is a ciliated turbellarian that measures between 0.4 to $0.8 \mathrm{~mm}$ in length. It has 2 prominent eye spots situated anteriorly (Burt \& Bance 1981, Pike \& Wink 1986, Tyler \& Burt 1988) and an oral-genital pore located at the posterior end (Fig. 1).

Urastoma cyprinae has been reported as free-living in marine mud and on algae (Marcus 1951, Westblad 1955). It has also been described on the gills of various bivalve species, including the clams Tridacna maxima and T. gigas (Goggin \& Cannon 1989), and the mussels Mytilus edulis (Fleming et al. 1981, Teia dos Santos \& Coimbra 1995) and M. galloprovincialis (Noury-Sraïri et al. 1990, Murina \& Solonchenko 1991, Robledo et al. 1994, Trotti et al. 1998). In Atlantic Canada, this worm (Fig. 2) has been observed in the eastern oyster Cras-

•E-mail: nicole.t.brun@eudoramail.com sostrea virginica (Burt \& Drinnan 1968, Fleming et al. 1981, Fleming 1986, Boghen et al. 1993).

The nature of the host-parasite relationship has never been well-defined. Although Burt \& Drinnan (1968) and Fleming et al. (1981) consider Urastoma cyprinae to be a commensal in oysters, and therefore, not harmful to its host, a more recent study (Robledo et al. 1994) has shown that the worm is responsible for serious destruction of host gill tissue in the mussel Mytilus galloprovincialis.

Fleming (1986) suggested that, in oysters, Urastoma cyprinae feeds on the mucus coating the gills. This, however, has never been the subject of any scientific investigation. If it can be shown that the worms are attracted to mucus, such a finding would support this contention.

The current study attempts to determine (1) if there is a definite attraction of Urastoma cyprinae to oysters, (2) how this compares to other molluscan species and (3) to establish whether mucus plays a role in attracting the worm to its host. 


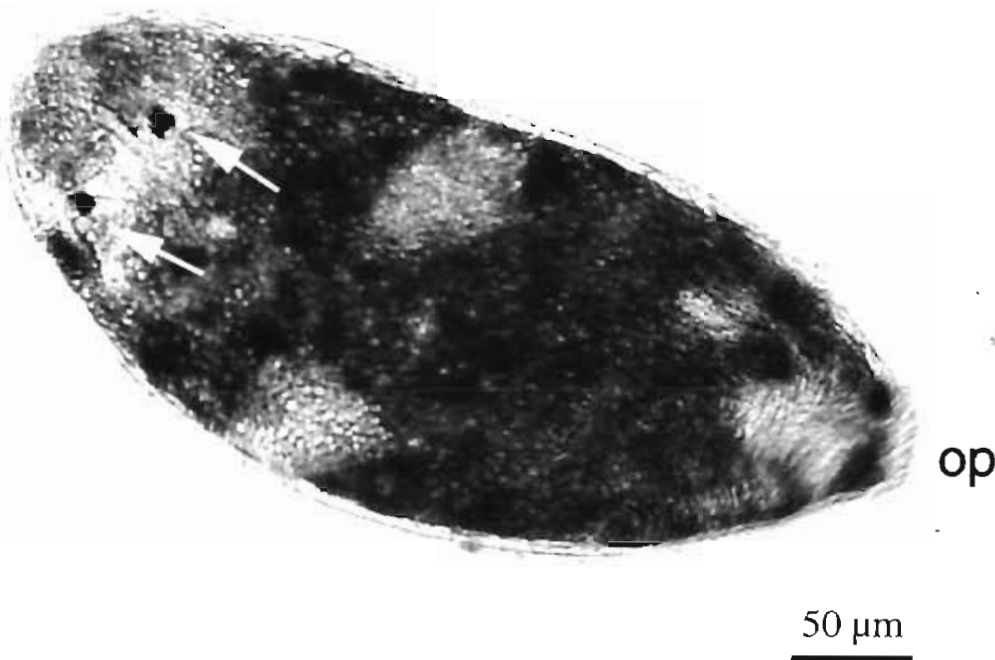

Fig. 1 Whole mount of Urastoma cyprinae. Arrows: eyes, op: oral-genital pore

Laboratory study. Seven experiments were conducted between the spring of 1995 and the fall of 1997. using wild oysters infected with Urastoma cyprinae collected at low tide in Shippagan Bay, New Brunswick. The oysters were transported in plastic bags to the Université de Moncton at either $4^{\circ} \mathrm{C}$ for Expts 1 and 2 or at ambient water temperatures of 20 to $23^{\circ} \mathrm{C}$ for Expts 3 to 7 . The oysters were opened and the worms were removed from the gills using a Pasteur pipette. They were divided into groups of 60 to 100 depending on the experiment (see below), and maintained in glass Petri dishes in filtered sea water (25\%) for $12 \mathrm{~h}$. All experiments were conducted at room temperature (22 to $23^{\circ} \mathrm{C}$ ) and in total darkness (based on our findings from Expt 1 ) in specifi-

\section{MATERIAL AND METHODS}

Field study. In June 1997, 300 adult oysters Crassostrea virginica, 300 mussels Mytilus edulis, and 300 clams Mya arenaria were obtained from the following commercial culture operations in Atlantic Canada: Cocagne Oyster Farm, Chiasson Aquaculture and Mills Sea Food Ltd. Ten bivalves of each species were dissected and carefully examined under a dissecting microscope to make certain that they were free of $U$. cyprinae. The molluscs were combined and subsequently separated into 3 heterogeneous groups, each group consisting of 100 animals of each of the 3 species. These were placed into standard Vexar bags $10.6 \mathrm{~m} \times$ $1.2 \mathrm{~m}, 1 \mathrm{~cm}$ mesh) and anchored on the ocean bottom along a beach in Shippagan Bay (New Brunswick, Canada), in an area where Urastoma cyprinae is known to occur. The bags were held at a depth of $25 \mathrm{~cm}$ (below low tide), and separated from each other by distances of $4 \mathrm{~m}$. Sampling was conducted every 3 to 4 wk over 5 mo, at which time 10 molluscs of each species were collected from each bag for a composite sample size of $\mathrm{n}=90$. The animals were transported in plastic bags on ice to the Université de Moncton and were examined for $U$. cyprinae under a dissecting microscope within $48 \mathrm{~h}$ of arrival. A total of 150 molluscs of each of the 3 species were collected and examined (see Table 1).

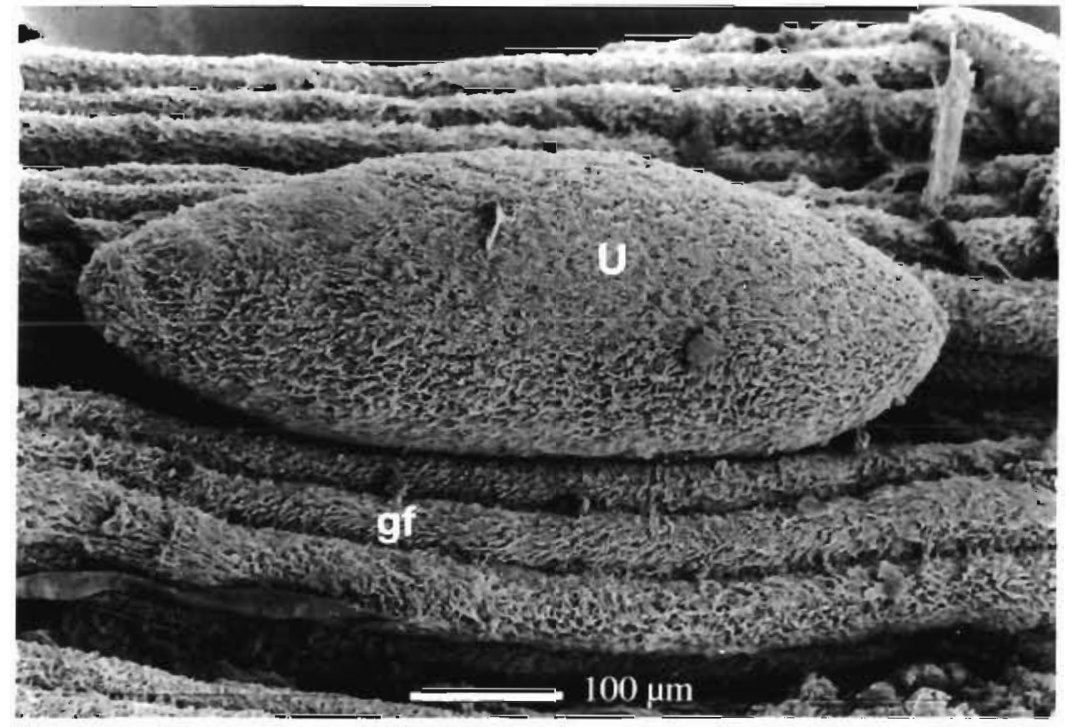

Fig. 2. Urastoma cyprinae. Scanning electromicrograph of gill worm on the oyster gill filaments. u: U. cyprinae, gf: gill filaments 


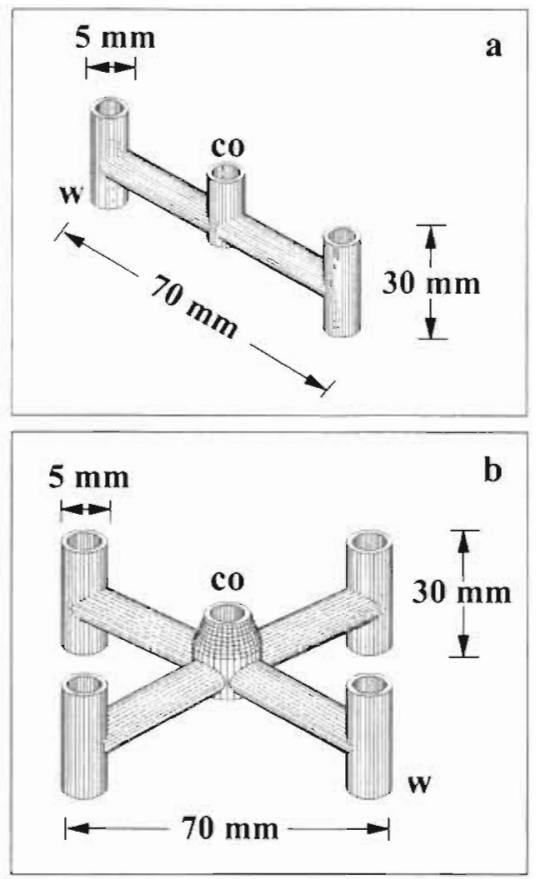

Fig. 3. Specially designed glass chambers used in experiments with Urastoma cyprinae. (a) 2-well glass chamber;

(b) 4-well glass chamber. co: central opening, w: well

A total of 10 trials using 60 worms trial ${ }^{-1}$ was undertaken. $U$. cyprinae were introduced into the chambers through the central opening and after 60 min the wells were drained with a pipette and the worms were counted under a dissecting microscope.

Expts 2 to 4 explored the extent of attraction of Urastoma cyprinae to whole oysters versus sea water (5 trials, 60 worms trial ${ }^{-1}$ ), whole oysters versus whole mussels (10 trials, 60 worms trial ${ }^{-1}$ ) and whole oysters versus whole clams (10 trials, 60 worms trial $\left.{ }^{-1}\right)$. The possible attractants were mixed with an equal amount of filtered sea water ( $25 \%$ ) and homogenized for $2 \mathrm{~min}$, after which the homogenates were diluted with filtered sea water at 1:10 (v/v) homogenate:sea water. The mixtures were subsequently centrifuged for $5 \mathrm{~min}$ at $3800 \mathrm{rpm}(2300 \times \mathrm{g})$, and the semi-formed pellets were collected by pipette and introduced into the wells of the glass chambers. This was immediately followed by the addition of sea water and $U$. cyprinae, as previously described for Expt 1.

Expts 5 and 6 were conducted using the 2-well chambers to test the attraction of Urastoma cyprinae to the following potential attractants:isolated oyster mucus versus oyster body (without gills) and isolated oyster mucus versus gills. These studies were based on 10 trials ( 60 worms trial ${ }^{-1}$ ). Expt 7 made use of the 4 -well chambers (Fig. 3b) and explored the attraction of $U$. cyprinae to the following stimulants: isolated oyster mucus versus gills versus mucus-free gills versus sea water. Processing of all stimulants was similar to that described above, with the exception of isolated oyster mucus and mucus-free gills.

For the preparation of isolated oyster mucus, $3 \mathrm{ml}$ of mucus was carefully drawn by pipette from the oyster gills, diluted with 10 parts filtered sea water $(25 \%)$ and concentrated at $3800 \mathrm{rpm}$ for $5 \mathrm{~min}$. Preparation of mucus-free gills involved gentle rinsing of isolated gills with filtered sea water 5 to 6 times, followed by homogenization of gill tissue and centrifugation as described above.

Student $t$-tests were employed to analyze the data based on the findings using the 2-well glass chambers. A 1-way ANOVA, followed by the Tukey multiple comparisons test was used to analyze the data based on the experiment employing the 4 -well glass chambers (Zar 1984).

\section{RESULTS}

The field study demonstrates that Urastoma cyprinae is more attracted to oysters than to the other molluscan species (Table 1). U. cyprinae is consistently more prevalent in oysters (100\%), compared to mussels ( 0 to $16.6 \%$ ) and clams (3.3 to $33.3 \%)$. This tendency is also reflected by the average mean number of worms per oyster (45.3 to 346.9) compared to individual mussels (0 to 0.03 ) and clams (0.07 to 0.6$)$ respectively.

The results of the $t$-tests based on the data using the 2 -well glass chambers are summarized in Table 2. Expt 1 (Fig. 4a) demonstrates that Urastoma cyprinae is

Table 1. Prevalence, mean and range of intensity of Urastoma cyprinae in Crassostrea virginica, Mytilus edulis and Mya arenaria in Shippagan Bay during the summer of 1997

\begin{tabular}{|c|c|c|c|c|c|}
\hline $\begin{array}{l}\text { Date } \\
\text { collected }\end{array}$ & Host & n & $\begin{array}{c}\text { Prevalence } \\
(\%)\end{array}$ & $\begin{array}{l}\text { Inte } \\
\text { Mean }^{a}\end{array}$ & $\begin{array}{l}\text { nsity } \\
\text { Range }\end{array}$ \\
\hline Jun 24 & $\begin{array}{l}\text { C. virginica } \\
M \text {. edulis } \\
M \text {. arenaria }\end{array}$ & $\begin{array}{l}30 \\
30 \\
30\end{array}$ & $\begin{array}{c}100 \\
0 \\
3.3\end{array}$ & $\begin{array}{c}45.3 \\
0 \\
0.1\end{array}$ & $\begin{array}{c}1-50 \\
0 \\
3-3\end{array}$ \\
\hline Jul 21 & $\begin{array}{l}\text { C. virginica } \\
M \text {. edulis } \\
M \text {. arenaria }\end{array}$ & $\begin{array}{l}30 \\
30 \\
30\end{array}$ & $\begin{array}{l}100 \\
13.3 \\
16.6\end{array}$ & $\begin{array}{l}309.5 \\
0.3 \\
0.2\end{array}$ & $\begin{array}{c}49-656 \\
1-4 \\
1-2\end{array}$ \\
\hline Aug 20 & $\begin{array}{l}C . \text { virginica } \\
M \text {. edulis } \\
M . \text { arenaria }\end{array}$ & $\begin{array}{l}30 \\
30 \\
30\end{array}$ & $\begin{array}{l}100 \\
16.6 \\
33.3\end{array}$ & $\begin{array}{l}346.9 \\
0.1 \\
0.6\end{array}$ & $\begin{array}{c}42-944 \\
1-2 \\
1-5\end{array}$ \\
\hline Sep 19 & $\begin{array}{l}C . \text { virginica } \\
M \text {. edulis } \\
M \text {. arenaria }\end{array}$ & $\begin{array}{l}30 \\
30 \\
30\end{array}$ & $\begin{array}{c}100 \\
0 \\
10\end{array}$ & $\begin{array}{c}97.6 \\
0 \\
0.1\end{array}$ & $\begin{array}{c}23-251 \\
0 \\
1-1\end{array}$ \\
\hline Oct 7 & $\begin{array}{l}\text { C. virginica } \\
M \text {. edulis } \\
M \text {. arenaria }\end{array}$ & $\begin{array}{l}30 \\
30 \\
30\end{array}$ & $\begin{array}{c}100 \\
0 \\
6.6\end{array}$ & $\begin{array}{c}313 \\
0 \\
0.07\end{array}$ & $\begin{array}{c}18-833 \\
0 \\
1-1\end{array}$ \\
\hline
\end{tabular}


negatively phototactic $(\mathrm{p}<0.001)$. Results of Expts 2 through 4 (Fig. 4 b to d) show that $U$. cyprinae is more attracted to oysters compared to sea water $(p=0.028)$, and this phenomenon is also evident when the worms are offered a choice between oysters and mussels $(\mathrm{p} 0<0.001)$, and oysters and clams ( $\mathrm{p}=0.020)$.

Data from Expts 5 and 6 indicate that Urastoma cyprinae is more attracted to isolated oyster mucus $(p=0.004$ ) than to the oyster body (without gills), but there is no significant difference in attraction $(\mathrm{p}=$ 0.174 ) when $U$. cyprinae has to choose between isolated oyster mucus and isolated gill tissue (Fig. 4e,f).

In Expt 7 (Table 3), the Tukey test confirms that Urastoma cyprinae is most attracted to isolated oyster mucus, followed by gills, mucus-free gills and sea water respectively (Fig. 5). Examination of the normal probability plots for each attractant show the residuals are approximately normal. The standard deviation varies from approximately 3 to 9 among the 4 possible attractants. As a consequence a non-parametric test was also carried out to confirm the ANOVA results.

\section{DISCUSSION}

Although Urastoma cyprinae occurs as a free-living organism (Marcus 1951. Westblad 1955), it has also been observed on the gills of various bivalve molluscs (Burt \& Drinnan 1968, Fleming et al. 1981, Fleming 1986, Goggin \& Cannon 1989, Noury-Sraïri et al. 1990, Murina \& Solonchenko 1991, Robledo et al. 1994, Teia dos Santos \& Coimbra 1995). Burt \& Drinnan (1968) described the association between $U$. cyprinae and the eastern oyster as being commensal. More recently, certain authors (Murina \& Solonchenko 1991, Teia dos Santos \& Coimbra 1995) have suggested that $U$. cyprinae induces pathology in mussels Mytilus galloprovincialis and $M$. edulis. Robledo et al. (1994) have shown conclusively that in the case of $M$. galloprovincialis, $U$. cyprinae causes serious disruption of gill filaments and significant hemocytic infiltration in the affected areas.

Table 2. Results of the Student $t$-tests for equality between the number of worms attracted to each stimulant of a tested pair

\begin{tabular}{|llllrrc|}
\hline Expt & Stimulant & $X^{\mathrm{a}} \pm \mathrm{SE}^{\mathrm{b}}$ & Stimulant & $X^{\mathrm{a}} \pm \mathrm{SE}^{\mathrm{b}}$ & $\mathrm{n}$ & $\mathrm{p}$ \\
\hline 1 & Dark & $36.4 \pm 1.1$ & Light & $26.3 \pm 1.1$ & 10 & $\mathrm{p}<0.001$ \\
2 & Oysters & $37.0 \pm 2.1$ & Sea water & $23.0 \pm 2.1$ & 5 & $\mathrm{p}=0.028$ \\
3 & Oysters & $42.1 \pm 2.5$ & Mussels & $12.5 \pm 1.3$ & 10 & $\mathrm{p}<0.001$ \\
4 & Oysters & $33.7 \pm 3.1$ & Clams & $18.0 \pm 2.6$ & 10 & $\mathrm{p}=0.020$ \\
5 & Mucus & $37.4 \pm 2.2$ & Body (no gills) & $21.2 \pm 2.0$ & 10 & $\mathrm{p}=0.004$ \\
6 & Mucus & $32.5 \pm 2.2$ & Gills & $26.0 \pm 2.2$ & 10 & $\mathrm{p}=0.174$ \\
A Average number of worms attracted to a given stimulant & & \\
'Standard error on the mean \\
\multicolumn{7}{l}{}
\end{tabular}
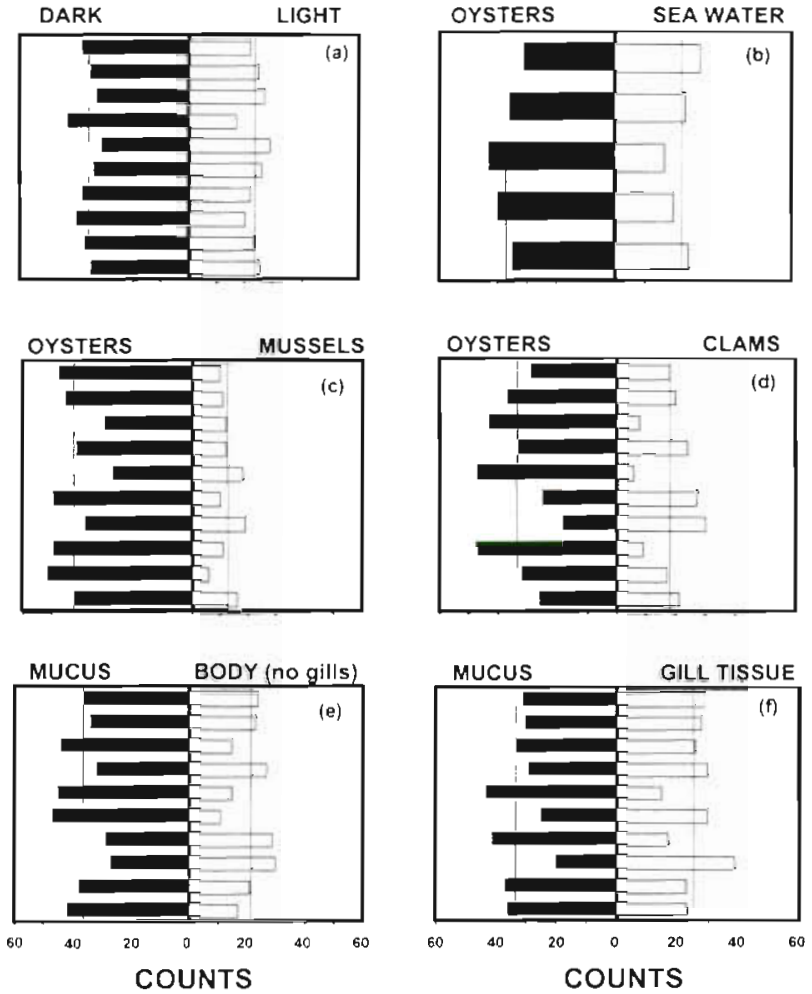

Fig. 4. Urastoma cyprinae. Number of gill worms recovered in each well containing the respective materials tested. Each bar represents 1 trial of the total number of $U$. cyprinae recorded. (a) Number $U$. cyprinae depicted in wells under light and dark conditions (Expt 1); (b) number of worms attracted to ayster versus sea water (Expt 2); (c) number of $U$. cyprinae attracted to oysters versus mussels (Expt 3); (d) number of worms attracted oysters versus clams (Expt 4); (e) number of $U$. cyprinae attracted to isolated oyster mucus versus oyster body with gills removed (Expt 5); (f) number of worms attracted to isolated oyster mucus versus gills (Expt 6). Vertical lines indicate the average number of $U$. cyprinae for all trials for each stimulant tested

These authors signal that $U$. cyprinae may be a potential threat to the mussel industry in Northern Spain.

Given the economic importance of the oyster industry in Eastern Canada, valued at 2.6 million dollars in 1995, a closer examination of the nature of the host-parasite relationship between Urastoma cyprinae and Crassostrea virginica is warranted.

Our work confirms that Urastoma cyprinae is highly attracted to oysters and that their presence in the host is not coincidental. Furthermore, the field work and laboratory Expts 2 to 4 indicate that $U$. cyprinae shows a greater attraction to oysters than to other native molluscan species. 
Table 3. P-values for the Tukey multiple comparisons test based on the data using the 4 -well glass chambers (Expt 7)

\begin{tabular}{|lcccc|}
\hline & Mucus & Gills & $\begin{array}{c}\text { Gills } \\
\text { (mucus removed) }\end{array}$ & Sea water \\
\hline Mucus & & \multicolumn{3}{c}{} \\
Gills & 1.000 & 0.187 & 0.002 & 0.000 \\
Gills (mucus removed, & 0.187 & 1.000 & 0.149 & 0.001 \\
Sea water & 0.000 & 0.001 & 1.000 & 0.086 \\
& & & 0.086 & 1.000 \\
\hline
\end{tabular}

Fleming (1986) suggests that the turbellarian may be feeding on the mucus secreted by oyster gills. While the present research did not focus on the worm's diet, our results clearly indicate a definite attraction of Urastoma cyprinae to isolated oyster mucus. The attraction of $U$. cyprinae to both isolated oyster mucus and oyster gills is perhaps to be expected, given the fact that gills are heavily coated in mucus, and that the latter plays an integral part in the suspension-feeding of bivalve molluscs (Ward et al. 1994, Ward 1996).

In vivo studies on suspension-feeding in bivalves using endoscopic techniques (Ward 1996) reveal that mucus present in the dorsal tracts is of low-viscosity and that particles are transported suspended in a mucus-slurry. This is qualitatively different from the high-viscosity mucus present along the ventral margins, in which material is bound in a continuous mucus string (Beninger et al. 1993). It would be an interesting challenge to establish if there is a correlation between the number of Urastoma cyprinae on specific regions of the oyster gills and mucus composition and flow. Such information may prove to be useful in future studies that focus on the incidence of $U$. cyprinae in relation to the rate of growth of oysters as well as the final quality of the cultured product.

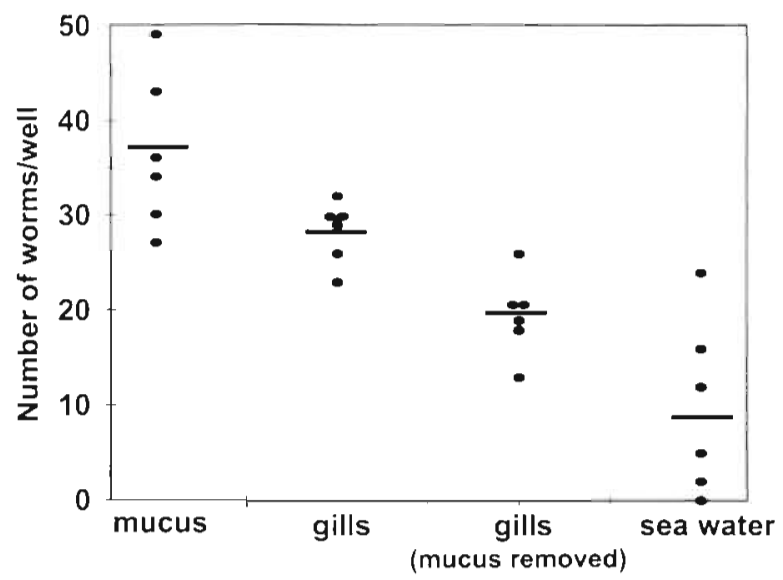

Fig. 5. Urastoma cyprinae. Number of gill worms (points) present in each well containing the following materials tested during each of the 6 trials (Expt 7): isolated oyster mucus, gills free of mucus and sea water. Bars represent the mean number of worms for each of the 4 substances
Acknowledgements. We would like to express our gratitude to Dr H. Rosenthal (University of Kiel, Germany), Dr M. D. B. Burt (Huntsman Marine Science Centre, St. Andrews, NB, Canada) and Dr G. Miron (Department of Biology, Université de Moncton, NB, Canada), for reviewing our manuscript and for their very helpful comments and suggestions. We are also grateful to Mr John Dalgleish (Department of Physics, Université de Moncton, NB, Canada) and Professor Charles Maillet (School of Engineering, Université de Moncton, NB, Canada) for their technical assistance with the construction and the drawings of the experimental chambers used in the present study. Financial support provided to the senior author by the Faculty of Research and Graduate Studies of the Universite de Moncton is appreciated. This project is part of the Richibucto Environment and Resource Enhancement Program.

\section{LITERATURE CITED}

Beninger PG, St-Jean S, Poussart Y, Ward E (1993) Gill function and mucocyte distribution in Placopecten magellanicus and Mytilus edulis (Mollusca: Bivalvia): the role of mucus in particle transport. Mar Ecol Prog Ser 98:275-282

Boghen AD, Allard J, Bataller E (1993) Rapport final et recommandations sur le programme de monitoring pour la côte est du Nouveau-Brunswick, Centre de recherche en sciences de l'environnement. Université de Moncton, Moncton, NB

Burt MDB, Bance GN (1981) Ultrastructure of the eye of Urastoma cyprinae (Turbellaria, Allocoeoela). Hydrobiologia $84: 276$

Burt MDB, Drinnan RE (1968) A microturbellarian found in oysters of the coast of Prince Edward Island. J Fish Res Board Can 25(11):2521-2522

Fleming LC (1986) Occurrence of symbiotic turbellarians in the oyster, Crassostrea virginica. Hydrobiologia 132: $311-315$

Fleming LC, Burt MDB, Bacon GB (1981) On some commensal Turbellaria of the Canadian East Coast. Hydrobiologia $84: 131-137$

Goggin CL, Cannon LRG (1989) Occurrence of a turbellarian from Australian tridacnid clams. Int J Parasitol 19(3): $345-346$

Marcus E (1951) Turbellaria Brasilieros (9) Boletins da faculdade filosofia ciencias e letras, Universidade Sao Paolo. Zoologia 16:5-215

Murina GV. Solonchenko Al (1991) Commensals of Mytilus galloprovincialis in the Black Sea: Urastoma cyprinae (Turbellaria) and Polydora ciliata (Polychaeta). Hydrobiologia 227:385-387

Noury-Sraïri N, Justine JL, Euzet L (1990) Ultrastructure du tégument et des glandes sous épithéliales de Urastoma cyprinae ('Prolecithophora'), turbellarié parasite de Mollusque. Ann Sci Nat Zool 11(Ser 13):53-71

Pike A.W, Wink R (1986) Aspects of photoreceptor structure and phototactic behavior in Platyhelminthes, with particular reference to the symbiotic turbellarian, Paravortex. Hydrobiologia 132:101-104

Robledo JAF, Cáceres-Martínez J، Sluys R, Figueras A (1994) The parasitic turbellarian Urastoma cyprinae (Platyhelminthes: Urastomidae) from blue mussel Mytilus galloprovincialis in Spain: occurrence and pathology. Dis Aquat Org 18:203-210

Teias dos Santos AM, Coimbra J (1995) Growth and production of raft-cultured Mytilus edulis L., in Ria de Aveiro: gonad symbiotic infestation. Aquaculture 132:195-211 
Trotti GC, Baccarani EM, Giannetto S, Giuffrida A, Paesanti F (1998) Prevalence of Myticola intestinalis (Copepoda: Mytilicolidae) and Urastoma cyprinae (Turbellaria: Hypotrichinidae) in marketable mussels Mytilus galloprovincialis in Italy. Dis Aquat Org 32:145-149

Tyler S, Burt MDB (1988) Lensing by a mitochondrial derivate in the eye of Urastoma cyprinae (Turbellaria, Prolecithophora). Fortsch Zool 36:229-234

Ward E (1996) Biodynamics of suspension-feeding in adult bivalve molluscs: particle capture, processing, and fate

Editorial responsibility: Albert Sparks,

Seattle, Washington, USA
J Invertebr Biol 1.15(3):218-231

Ward E, Newell RIE. Thompson RJ, MacDonald BA (1994) In vivo studies of suspension-feeding processes in the eastern oyster. Crassostrea virginica (Gmelin). Biol Bull 186: $221-240$

Westblad E (1955) Marine 'Alloeocoels' (Turbellaria) from North Atlantic and Mediterranean coast. Ark Zool $7(24)$ : 491-526

Zar JH (1984) Biostatistical analysis. Prentice-Hall Inc, Englewood Cliffs, NJ

Submitted: October 29, 1998; Accepted: May 2, 1999

Proofs received from author(s): July 29, 1999 